\title{
Strategies for Increasing the Competitiveness of Krakatau Steel Company in The Free Trade Area of Batam to Support the Defense Equipment
}

\author{
Hamirudin ${ }^{1} \square$ and Ruruh Prasetya ${ }^{2}$ \\ ${ }^{12}$ Defense Industri, Department of Indonesia Defense University, Indonesia \\ $\checkmark$ Corresponding Author: Hamirudin, E-mail: Hamirudin.id@gmail.com
}

ARTICLE INFORMATION ABSTRACT

Received: 09 October 2021

Accepted: 16 November 2021

Published: 19 November 2021

DOI: 10.32996/jmcie.2021.2.2.4

\section{KEYWORDS}

Batam Free Trade Area, Competitiveness Criteria, Krakatau Steel, National Defense, Strategy to Increase Competitiveness
The steel plate market in the Batam Free Trade Zone is very large, namely $75 \%$ of the Indonesian market share. PT Krakatau Steel's steel plate products are not competitive in the Batam Free Trade Area, especially in terms of price and long delivery times. So, a strategy is needed to increase competitiveness. This type of research is a quasiqualitative research method with interviews, questionnaires, observation, and literature study. In this study, there are two problem formulations, namely how to determine the criteria for competitiveness and how to improve the strategy for increasing the competitiveness of PT Krakatau Steel's steel plate in the Batam Free Trade Area. In determining the criteria for competitiveness, AHP analysis is used. For strategies to increase competitiveness using the SWOT-AHP analysis. The results showed that the criteria affecting the competitiveness of steel were Manufacture Strategy with a weighting value of 0.526 with sub-criteria for cost, quality, delivery, and flexibility. The SWOT analysis shows that the strategy currently used by PT Krakatau Steel is SO. Based on the results of the SWOT-AHP analysis research, it was found that the competitiveness of PT Krakatau Steel could still be improved with the ST strategy which was more relevant to the situation in the Batam Free Trade Area.

\section{Introduction}

Indonesia is the largest archipelagic country in the world with a total of 17,449 islands, with a sea area of 5.9 million km, and a coastline of $81,000 \mathrm{~km}$ (Marsetio, 2018). Indonesia's geographical position which is in a tropical area rich in natural resources and is in a cross position between two continents (the continents of Australia and Asia) and two oceans (the Pacific Ocean and the Indian Ocean) causes Indonesian waters to become international shipping lanes that are always busily navigable by tourists. expedition ships from all over the world. Faced with the vast waters that must be secured by the competent authority, it takes many warships to be built, so that the security task can be carried out properly. In the manufacture of warships, a reliable and experienced shipyard industry is needed and supported by equipment and human resources that have good capacity and capability.

National resources are national facilities and infrastructure that can be utilized to face threats to national defense efforts (Ministry of Defense, 2015). The shipbuilding industry is one of the national facilities and infrastructure so that if at any time there is a war, the shipbuilding industry, both state-owned and private, will be fully involved to support the fulfillment and maintenance of the required defense and security equipment. The shipbuilding industry is included in the defense industry and is a national resource (Law No. 16, 2012). The Steel Industry in the Defense Industry cluster is in tier four, namely the raw material industry. In the process of designing a ship, the main raw material needed is steel plate. Steel plate is the result of processing from iron ore which is processed using a blast furnace by going through various treatment processes so that it becomes the desired steel plate. Indonesia has the largest iron ore processing company in Southeast Asia and is a State-Owned Enterprise or BUMN, namely PT. Krakatau Steel is located in the city of Cilegon, Banten. PT Krakatau Steel's production activities include raw steel production, production,

Copyright: (c) 2021 the Author(s). This article is an open access article distributed under the terms and conditions of the Creative Commons Attribution (CC-BY) 4.0 license (https://creativecommons.org/licenses/by/4.0/). Published by Al-Kindi Centre for Research and Development, London, United Kingdom. 
and sales of semi-finished steel, and finished steel production including steel billets, HRC and CRC, steel wire rods (WR), reinforcing steel, profile steel, and steel pipes. Steel production can be adjusted to the specifications required by consumers.

However, in the current era of free trade, the practice of implementing dumping often occurs in countries whose economies are already very strong, of course, this will pose a separate threat to BUMN PT Krakatau Steel in competing in the global market because competitors can carry out dumping. Industrial dumping activities in competing countries will receive subsidies from their government for their products, with these subsidies they have the opportunity to lower the prices of their products. With competitive prices, they hope to be able to sell their products in bulk, so that the profits are expected to be even greater. The implementation of this dumping practice causes losses to the country that imports the product. Domestic industries will be unable to compete with these products. To protect their domestic industries, importing countries will apply anti-dumping import duties. With the implementation of this import duty, it is hoped that domestic industries can be competitive and can maintain their production. Indonesia itself has issued many regulations regarding the application of anti-dumping import duties on products that have been proven to carry out dumping practices.

The application of this Anti-Dumping Import Duty regulation cannot yet be applied in the Batam free trade area due to overlapping regulations in the free area. With this background, this study will discuss related to determining the criteria that affect the competitiveness of PT Krakatau Steel's HRP steel in the Batam Free Trade Area in supporting national defense and strategies to increase competitiveness that are suitable for PT Krakatau Steel's HRP steel plates in free areas. Batam in supporting the national defense.

\section{Research Methodology}

The research method used in this study is a qualitative approach with the type of quasi-qualitative research, which is meant by quasi-qualitative, namely research that uses a qualitative approach accompanied by quantitative data, in which the descriptive qualitative approach is not fully rooted in qualitative research, but also influenced by quantitative views so that the type of descriptive qualitative research is more accurately referred to as quasi-qualitative (Fajar \& Shofi, 2016). In addition, this study uses data collection techniques in the form of interviews, questionnaire surveys, and documentation. Meanwhile, to check the validity of the data, the researchers used data credibility, data transferability, data dependability, and data confirmability.

\section{Results and Discussion}

How to determine the criteria that affect the competitiveness of PT Krakatau Steel's HRP steel in the Batam Free Trade Area in supporting national defense, there are:

\subsection{Expert Selection}

Expert is the person who really understands the problem posed, feels the consequences of a problem, or has an interest in the problem. In this study, the expert is the Manager of Market research and development PT Krakatau Steel

\subsection{Competitiveness Criteria Data Validation}

Carry out a literature search related to competitiveness criteria. These competitiveness criteria and sub-criteria are taken from the opinions of several experts that researchers consider relevant to the Indonesian steel industry, including: (1) competitiveness with a competitive strategy with sub-criteria cost leadership, differentiation, and a combination of cost leadership and differentiation (Kim and Mauborgne, 2009 ), (2) Competitiveness criteria are Manufacturing strategy with sub-criteria of Cost, Quality, delivery and flexibility (Avella at al, 2016), (3) technology with sub-criteria of access to new technology, existing production capability, process improvement capability, product improvement capability and new product development capability (Sirikrai, et.al, 2016), (4) partnerships with sub-criteria of internal partnerships, partnerships with customers, partnerships with suppliers, and partnerships with potential competitors (Maisaroh, 2007). Of the four competitiveness criteria, then validation is carried out by experts whether the competitiveness criteria and sub-criteria that the researcher proposes are relevant to those used by PT Krakatau Steel at this time, or are not appropriate and need to be added. 
Table 1. Validated Competitiveness Criteria and Sub Criteria

\begin{tabular}{|c|c|}
\hline CRITERIA & SUB CRITERIA \\
\hline $\begin{array}{l}\text { Manufacture } \\
\text { Strategy }\end{array}$ & $\begin{array}{l}\text { - Cost, Quality, Delivery, } \\
\text { Flexibility }\end{array}$ \\
\hline $\begin{array}{l}\text { Competitive } \\
\text { Strategy }\end{array}$ & $\begin{array}{ll}\text { - } & \text { Cost Leadership } \\
\text { - } & \text { Differentiation } \\
\text { - } & \text { Cost Leadership dan } \\
& \text { differentiation } \\
\end{array}$ \\
\hline Technology & $\begin{array}{l}\text { - } \quad \text { Existing Production capability } \\
\text { - } \quad \text { Access to new technology } \\
\text { - } \quad \text { Process improvement } \\
\text { capability } \\
\text { - } \quad \text { Product improvement } \\
\text { capability } \\
\text { - } \quad \text { New productdevelopment } \\
\text { capability }\end{array}$ \\
\hline $\begin{array}{l}\text { Partnership/ } \\
\text { collaboration }\end{array}$ & $\begin{array}{ll}\text { - } & \text { External Partnership } \\
\text { Partnership with strategic } \\
\text { partners } \\
\text { - } \quad \text { Partnership with customers } \\
\text { - } \quad \text { Partnership with potential } \\
\text { competitors }\end{array}$ \\
\hline
\end{tabular}

Source: Processed by Researchers, 2021

From table 1, the researcher made a pair-wise comparison questionnaire of each of the competitiveness criteria and sub-criteria. Then the weight calculation is carried out using AHP analysis. From the results of the study, the results obtained

Table 2. The weighting of Competitiveness Criteria and Sub Criteria

\begin{tabular}{|c|c|}
\hline Criteria & Sub Criteria \\
\hline \multirow{4}{*}{$\begin{array}{l}\text { Manufacture Strategy } \\
(0,526)\end{array}$} & Cost $(0,420)$ \\
\hline & Quality $(0,296)$ \\
\hline & Delivery $(0,229)$ \\
\hline & Flexibility $(0,053)$ \\
\hline \multirow[t]{3}{*}{$\begin{array}{l}\text { Competitive Strategy } \\
(0,151)\end{array}$} & $\begin{array}{l}\text { Cost leadership } \\
(0,318)\end{array}$ \\
\hline & $\begin{array}{l}\text { Cost leadershipand } \\
\text { differensiation } \\
(0,588)\end{array}$ \\
\hline & $\begin{array}{l}\text { Differensiation } \\
(0,092)\end{array}$ \\
\hline \multirow[t]{5}{*}{ Technology $(0,255)$} & $\begin{array}{l}\text { Access to new } \\
\text { technology } \\
(0,053)\end{array}$ \\
\hline & Existing \\
\hline & $\begin{array}{l}\text { Production } \\
\text { Capability }(0,163)\end{array}$ \\
\hline & $\begin{array}{l}\text { New Product Development } \\
\text { Capability }(0,107)\end{array}$ \\
\hline & $\begin{array}{l}\text { Process improvement } \\
\text { capability }(0,409)\end{array}$ \\
\hline
\end{tabular}




\begin{tabular}{|l|l|}
\cline { 2 - 2 } & $\begin{array}{l}\text { Product Improvement } \\
\text { Capability }(0,266)\end{array}$ \\
\hline Product & Kemitraan dengan \\
Capability & Pelanggan \\
$(0,266)$ & $(0,538)$ \\
\cline { 2 - 2 } & Kemitraan dengan pesaing \\
& potensial $(0,085)$ \\
\cline { 2 - 2 } & Kemitraan dengan mitra \\
& strategis $(0,282)$ \\
\cline { 2 - 2 } & Kemitraan \\
& eksternal $(0,931)$ \\
\hline
\end{tabular}

Source: Processed by Researchers, 2021

A score of table 2 will be verified by an expert of PT Krakatau Steel. The results of the expert validation of PT Krakatau Steel said that the most dominant competitiveness criteria were the Manufacturing strategy. The rank of priority according to the expert served to table 3 .

Table 3. Results of Validation of Competitiveness Sub Criteria

\begin{tabular}{|l|l|}
\hline \multicolumn{1}{|c|}{ Sub-Criteria } & \multicolumn{1}{c|}{ Sequences } \\
\hline Cost & 1 \\
\hline Quality & 2 \\
\hline Deliverability & 3 \\
\hline Flexibility & 4 \\
\hline
\end{tabular}

Source: Processed by Researchers, 2021

From the results of expert validation, it shows that for the competitiveness sub-criteria of the relevant manufacturing strategy used by PT Krakatau Steel, the weighting order of the largest is cost, delivery, quality, and flexibility.

In determining the strategy that will be used to increase the competitiveness of Krakatau Steel in the Batam Free Trade Area, especially for the shipbuilding industry, it is carried out using a SWOT analysis (Strengths, Weaknesses, Opportunities, and Threats). identification for internal and external factors of the company.

\section{a. Internal Factor Analysis}

The identification of these factors is obtained from the results of the AHP weighting in determining the competitiveness criteria, for the results of the research on the competitiveness criteria, the researchers take the biggest factor as the Internal factor, namely Manufacturing Strategy (Cost, Quality, Delivery, and Flexibility). From the competitiveness criteria, the researchers grouped cost and delivery into weakness factors and for strength factors, quality, and flexibility. So that it can be concluded that the results of the analysis of the company's internal factors, namely Strengths and Weaknesses, can be summarized and mapped as follows:

\section{Strengths :}

- Quality (the result of AHP weighting of competitiveness criteria),

- Flexibility (the result of AHP's weighting of competitiveness criteria),

- Digitization (Krassmart) and has SNI standard.

\section{Weaknesses:}

- Price (the result of AHP weighting of competitiveness criteria),

- Delivery (the result of AHP weighting of competitiveness criteria),

- The technology used is not efficient (in the 70s),

- $\quad$ There is a minimum order and there is no Hub in Batam.

These factors are then analyzed by determining the strengths and weaknesses of the organization and then given the weight of the influence of the internal factors of the organization. From the important scale $(1,0)$ to the unimportant scale $(0,0)$ based on the internal influence of the organization. The next column contains a value scale for each factor by giving a scale of 1-4 with a value of 4 meaning very good for strengths and the opposite for weaknesses where a scale of 1 is good and a scale of 4 means very bad. The next column is the total weighted score of 3.32 with an accumulated strength factor of 1.71 and a weakness of 1.61 so that the assumption is that PT Krakatau Steel's strength factor is greater to cover the weakness factor. 
Table 4. IFAS Matrix

\begin{tabular}{|c|c|c|c|c|}
\hline No & Factor & $\begin{array}{l}\text { Weight } \\
(1-100 \%)\end{array}$ & $\begin{array}{l}\text { Score } \\
\text { Scale }\end{array}$ & $\begin{array}{l}\text { Weight } \\
\text { score }\end{array}$ \\
\hline a. & \multicolumn{4}{|l|}{ Strenght } \\
\hline 1 & $\begin{array}{l}\text { Good quality steel, } \\
\text { in accordance with } \\
\text { the established } \\
\text { international } \\
\text { classification. }\end{array}$ & 0.13 & 3 & 0.39 \\
\hline 2 & $\begin{array}{l}\text { Great payment } \\
\text { flexibility and sales } \\
\text { support }\end{array}$ & 0.15 & 4 & 0.60 \\
\hline 3 & $\begin{array}{l}\text { Digitization } \\
\text { (Krassmart). }\end{array}$ & 0.12 & 3 & 0.36 \\
\hline 4 & SNI certification & 0.12 & 3 & 0.36 \\
\hline \multicolumn{2}{|r|}{ Sub Total } & 0.52 & & 1.71 \\
\hline b. & \multicolumn{4}{|l|}{ Weakness } \\
\hline 1 & $\begin{array}{l}\text { KS steel prices are } \\
\text { more expensive } \\
\text { than foreign steel } \\
\text { prices in the Batam } \\
\text { Free Trade Area }\end{array}$ & 0.14 & 4 & 0.56 \\
\hline 2 & $\begin{array}{l}\text { Long delivery time } \\
\text { to Batam }\end{array}$ & 0.13 & 4 & 0.52 \\
\hline 3 & $\begin{array}{l}\text { The technology } \\
\text { used is not efficient } \\
\text { (the 70s) }\end{array}$ & 0.10 & 2 & 0.20 \\
\hline 4 & $\begin{array}{l}\text { There is a minimum } \\
\text { order and there is } \\
\text { no Hub in Batam. }\end{array}$ & 0.11 & 3 & 0.33 \\
\hline \multicolumn{2}{|c|}{ Sub Quantity } & 0.48 & & 1.61 \\
\hline \multicolumn{2}{|c|}{ Total } & 1 & & 3.32 \\
\hline
\end{tabular}

Source: Processed by Researchers, 2021

\section{b. External Factor Analysis}

External factors consist of opportunities (opportunities) and threats (threats) whereas External factors it is associated with PESTEL (Politics, Economy, Social, Technology, Environment, and Legal). In the analysis of external factors, the researcher relates it to Law No. 16 of 2012 on the Defense Industry. where one of PT Krakatau Steel is currently not included in the Ministry of Defense Defense Industry. And we also relate it to the regulations of the Batam Free Trade Area. So for the strategy to increase the competitiveness of PT Krakatau Steel's steel in the Batam free trade area, the external factors are as follows:

\section{Politics:}

to find out how local, national, regional, and international political developments affect the company's strategy. Where this study is related to the Batam-free area, the government policy regarding the protection of the domestic steel industry by issuing BMAD regulations cannot be applied in Batam. However, there are other, more supportive impacts on the national economy. This is a threat to the domestic steel industry.

\section{Economy:}


inflation, economic growth, export-import policies including government policies in fiscal and investment. From the economic aspect to expensive transportation costs to Batam which are more expensive than exports to Malaysia, gas energy costs have quadrupled, and iron ore raw materials are still imported.

\section{Social:}

the trend of steel sales in the Batam-free area, where the shipbuilding industry in Batam is more inclined to use imported steel from abroad, especially Singapore due to cheaper prices and fast delivery times than buying at Krakatau Steel.

\section{Technology:}

the threat is that the production machine owned by PT Krakatau Steel is a machine in the 70s so that the production machine cannot be efficient when compared to current production machines.

\section{Environment:}

the influence of the company's operations on the environment and its ecological impact. In accordance with what the Krakatau Steel team said that the production process at Krakatau Steel is very environmentally friendly because they have technology that can reduce emissions from coal so that the air produced is still within the tolerance required by the government.

\section{Legal:}

From the legal aspect in the Batam area. The Batam area is a free trade area, but there are regulations that cannot be enforced there, namely the BMAD which is expected to protect the domestic steel industry but in reality, this regulation cannot be applied.

Furthermore, the results of the analysis of the company's external factors, namely opportunities and threats can be summarized and mapped as follows:

\section{Opportunities:}

a. Large market share in Batam (60\%) many shipbuilding and offshore industries in Batam

b. The raw material for iron sand is abundant in Java. It is hoped that it can become a cheap alternative raw material.

c. Regulation on steel scrap is no longer waste so that it becomes an alternative raw material.

d. Enforcement of SNI for steel entering Indonesia so as to minimize incoming foreign steel

\section{Threat:}

a. The entry of steel from abroad and BMAD does not apply in Batam

b. The cost of transportation to Batam is expensive. Export shipping costs to Malaysia are cheaper than shipping to Batam

c. Energy prices increase (gas prices increase 4 times)

d. High raw material prices because domestic raw materials cannot be fulfilled

Table 5. EFAS Matrix

\begin{tabular}{|c|c|c|c|c|}
\hline No & Factor & $\begin{array}{l}\text { Weight } \\
(1-100 \%)\end{array}$ & $\begin{array}{l}\text { Score } \\
\text { Scale }\end{array}$ & $\begin{array}{l}\text { Weight } \\
\text { score }\end{array}$ \\
\hline c. & \multicolumn{4}{|l|}{ Opportunities } \\
\hline 1 & $\begin{array}{l}\text { Big market share in } \\
\text { Batam }(60 \%)\end{array}$ & 0.13 & 3 & 0.39 \\
\hline 2 & $\begin{array}{l}\text { The raw material for } \\
\text { iron sand is } \\
\text { abundant in Java. }\end{array}$ & 0.13 & 3 & 0.39 \\
\hline 3 & $\begin{array}{lr}\text { Regulations } & \text { on } \\
\text { steel scrap are no } \\
\text { longer waste so that } \\
\text { it becomes an } \\
\text { alternative } \\
\text { material. raw }\end{array}$ & 0.15 & 3 & 0.45 \\
\hline
\end{tabular}




\begin{tabular}{|c|c|c|c|c|}
\hline 4 & $\begin{array}{l}\text { Enforcement of SNI } \\
\text { for steel entering } \\
\text { Indonesia }\end{array}$ & 0.18 & 4 & 0.76 \\
\hline \multicolumn{2}{|r|}{ Sub Jumlah } & 0.60 & & 1.99 \\
\hline d. & \multicolumn{4}{|l|}{ Threats } \\
\hline 1 & $\begin{array}{l}\text { The entry of steel } \\
\text { from abroad and } \\
\text { the } \\
\text { applicability } \\
\text { BMAD in Batam }\end{array}$ & 0.10 & 1 & 0.1 \\
\hline 2 & $\begin{array}{l}\text { The cost of } \\
\text { transportation to } \\
\text { Batam is expensive. }\end{array}$ & 0.11 & 2 & 0.22 \\
\hline 3 & $\begin{array}{l}\text { Energy prices go up } \\
\text { (gas prices go up } 4 \\
\text { times) }\end{array}$ & 0.11 & 2 & 0.22 \\
\hline 4 & 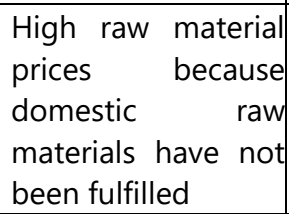 & 0.08 & 1 & 0.08 \\
\hline \multicolumn{2}{|c|}{ Sub Total } & 0.40 & & 0.62 \\
\hline \multicolumn{2}{|c|}{ Overall Total } & 1 & & 2.61 \\
\hline
\end{tabular}

Source: Processed by Researchers, 2021

Based on table 6 the overall priority of the SWOT factors, it is found that the results of AHP are weighted for a value of 0.526 , partnership with a value of 0.066, Competitive Strategy with a weighted value of 0.151 , and Technology with a weighted value of 0.255. All of the resulting weighting values are strategy, the result is that the ST strategy ranks first. So that the SO strategy used by PT Krakatau Steel is currently irrelevant to the situation in the Batam Free Trade Area, this is in accordance with the reality on the ground that a lot of imported steel enters Batam with more competitive prices and faster delivery times when compared to with products from PT Krakatau Steel. but based on the research results this strategy can still be improved by implementing an ST strategy that has better competitiveness.

\section{Conclusion}

1. The results of research with AHP analysis show that there are four main criteria that affect competitiveness, namely Manufacturing Strategy with weights through the consistency ratio test with the maximum allowable limit of 0.1 . So it can be concluded that the criteria that affect the competitiveness of PT Krakatau Steel's steel plate in the Batam Free Trade Area in supporting national defense are the Competitive Strategy which consists of sub-criteria: Cost (0.420), Quality (0.292), Delivery (0.229) and Flexibility (0.053). The results of validation with experts relevant to PT Krakatau Steel for the competitiveness subcriteria from the most priority are; cost, delivery, quality, and flexibility.

2. The results of the SWOT analysis show that from the IFAS matrix, a score of 3.32 is obtained. This result is obtained by summing the strength factor of 1.71 and the company's weakness factor of 1.61. So we get the assumption that the company's strengths can cover the company's weaknesses. Analysis of the EFAS matrix shows that the total value is 2.61 with an opportunity factor of 1.99 and a threat factor of 0.62 . From these results, it can be assumed that the opportunity factor can still cover the threat factor. The strategy implemented by PT Krakatau Steel at this time is an SO strategy that has been running well. Based on the results of research using SWOT-AHP, it was found that the strategy that can be an alternative to increase competitiveness today is the ST strategy, namely by looking for suppliers of raw materials at competitive prices, collaborating with national shipping companies that have a fixed schedule to Batam in product delivery to Batam. Batam, Implementing production efficiency, cooperating with Krakatau Posco for the market in Batam. 


\section{References}

[1] Avella, L., Fernandez, E., and Vazquez, C.J. (2001). Analisis of Manufacture Strategy as an Explanatory Factor of Competitiveness in the Large Spanish Industrial Firm, Int. J.

[2] Kementerian P. (2015). Buku Putih Pertahanan Indonesia.

[3] Kim, W.C., and Mauborgne, R. (2009). Blue Ocean Strategy (Strategi Samudra Biru), Ciptakan Ruang Pasar Tanpa Pesaing dan Biarkan Kompetisi Tak Lagi Relevan, Havard Business School Publishing Corporation.

[4] Maisaroh, S. (2007). Peningkatan Daya Saing melalui konsep Value Chain dan Kemitraan, AKMENIKA UPY, Volume 1, 2007.

[5] Marsetio. (2018). Mengembalikan kejayaan Maritim Indonesia, Universitas Pertahanan

[6] Sirikrai, S.B., Tang, J.C.S. (2006). Industrial Competitiveness Analysis: Using the Analytic Hierarchy Process, The Journal of High Technology

[7] Managemenet Research, Volume 17, Issue 1, Pages 71-83.

[8] Fajar, A. N., \& Shofi, I. M. (2016). Goal Model to Business Process Model: A Methodology for Enterprise Government Tourism System Development. International Journal of Electrical\& Computer Engineering, 6(6).

[9] Undang U (2012) tentang Industri Pertahanan 